\title{
A simple method for isolation of genomic DNA from fresh and dry leaves of Terminalia arjuna (Roxb.) Wight and Argot
}

\author{
Vishal P. Deshmukh \\ Department of Botany \\ Sant Gadge Baba Amravati University \\ Amravati 444602, India \\ Tel: 0917212662207 \\ Fax: 0917212660949 \\ E-mail: vishalpdeshmukh@yahoo.com \\ Prashant V. Thakare* \\ Department of Biotechnology \\ Sant Gadge Baba Amravati University \\ Amravati 444602, India \\ Tel: 0917212662249 \\ Fax: 0917212660949 \\ E-mail: prashantthakare123@rediffmail.com
Uddhav S. Chaudhari
Department of Botany
Amravati 444602, India
Tel: 0917212662207
Fax: 0917212660949 \\ Sant Gadge Baba Amravati University \\ E-mail: druschoudhary@yahoo.co.in \\ Prashant A. Gawande \\ Department of Botany \\ Sant Gadge Baba Amravati University \\ Amravati 444602, India \\ Tel: 0917212662207 \\ Fax: 0917212660949 \\ E-mail: prashantagawande@india.com
}

Financial support: Late Mukand Narhari Kale Research Scholarship Sant Gadge Baba Amravati University, Amravati.

Keywords: Ayurveda, DNA extraction, medicinal plant, Terminalia species.

Abbreviations: PCR: polymerase chain reaction

RAPD: random amplification of polymorphic DNA

Current protocols for isolation of genomic DNA from Terminalia Arjuna have their own limitations due to the presence of high content of gummy polysaccharides and polyphenols. DNA isolated by these protocols is contaminated with a yellowish, sticky and viscous matrix. In our modified DNA isolation method polysaccharides and polyphenols are removed prior to the precipitation of the DNA. Then the genomic DNA was precipitated using isopropanol. This protocol yielded a high molecular weight DNA isolated from fresh as well as dry leaves of $T$. Arjuna, which was free from contamination and colour. Isolated DNA can be used for restriction digestion and PCR amplification. The main objective of the present protocol is to provide a simple method of isolation of DNA, using in house prepared reagents.

Terminalia arjuna (Roxb.) Wight and Arnot (family Combretaceae) is a large tree distributed throughout India and is known for its very high medicinal value in ancient Ayurveda and Unani medicine therapies (Pasquini et al. 2002). Herbal drug therapies are getting importance because of their easy availability and less side effects as compared to other medicinal therapies. In ayurvedic literature $T$. arjuna is known for its various medicinal properties like tonic, anthelmintic, styptic and alexiteric (Scassellati-Sforzolini et al. 1999). The bark of T. arjuna is known for treating heart diseases, coronary artery diseases

*Corresponding author 
and hypercholesterolemia (Miller, 1998). The plant has considerable importance as timber and its tannin containing nuts (Ohri, 1996).

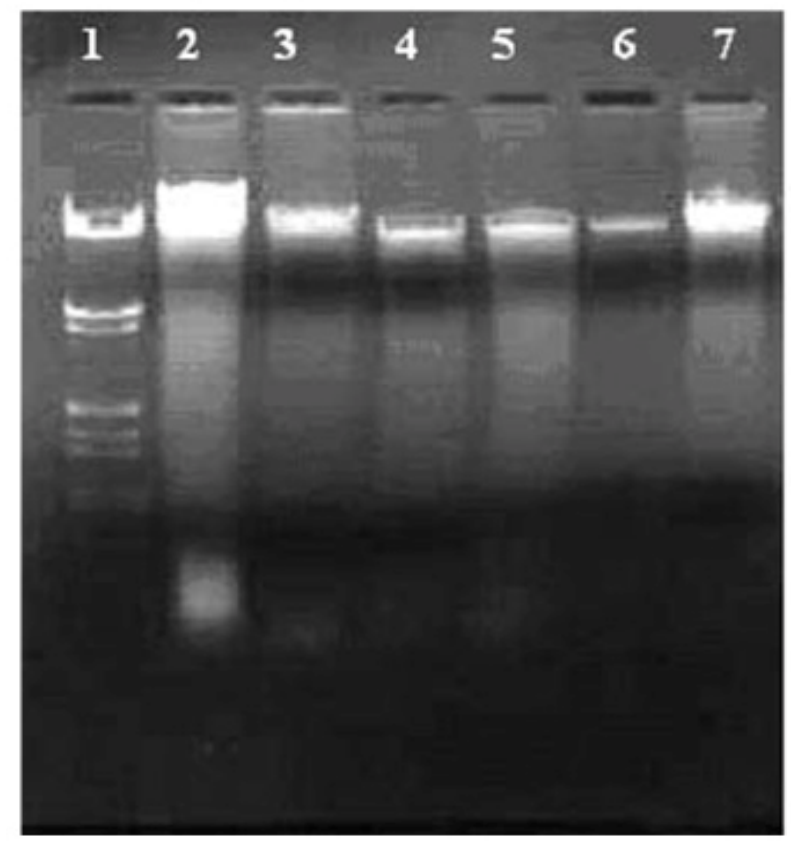

Figure 1. DNA isolated from fresh and dry leaves on $0.7 \%$ agarose gel from left to right. Lane 1: $\lambda$ DNA Digested with Eco R I + Hind III; Lane 2: Terminalia arjuna fresh leaves; lane 3: Terminalia arjuna dry leaves; lane 4: Terminalia tomentosa fresh leaves; lane 5: Terminalia tomentosa dry leaves; lane 6: Terminalia bellerica fresh leaves; lane 7: Terminalia chebula fresh leaves.

Polyphenolic contents were reported from $T$. arjuna by Bajpai et al. (2005). A little is known about the molecular biology of T. arjuna (Bharani et al. 2002), due to the presence of polyphenolic and polysaccharide compounds, which acts as inhibitors during isolation of DNA. During the isolation of DNA from perennial plant tissue like leaves of $T$. arjuna, these inhibitory substances get precipitated along with the DNA, thus deteriorating the quality and yield of the DNA. To solve this problem, we tried several protocols, which were reported previously along with various modifications from both fresh and dry leaves, but none yielded DNA free from polysaccharides and polyphenols. These situations required the development of a new protocol for the isolation of genomic DNA of high purity from $T$. arjuna.

We describe a simple DNA isolation protocol that yields high quality genomic DNA from fresh as well as dry leaves of $T$. arjuna. The isolated DNA has proved amenable to polymerase chain reaction (PCR) amplification and restriction digestion. The proposed method makes use of inhouse prepared and readily available reagents and thus provides an alternative to the use of commercial DNA isolation kits. This protocol is applicable to other similar species of family Combretaceae e.g. Terminalia bellerica, Terminalia chebula and Terminalia tomentosa.

\section{MATERIALS AND METHODS}

\section{Collection of plant material}

Juvenile leaves of T. arjuna, T. bellerica, T. chebula and T. tomentosa were collected from different locations of Melghat Tiger Reserve, Maharashtra, India (Latitudes $21^{\circ}$ $15^{\prime} \mathrm{N}$ and $21^{\circ} 45^{\prime} \mathrm{N}$, Longitudes $76^{\circ} 57^{\prime} \mathrm{E}$ and $77^{\circ} 33^{\prime} \mathrm{E}$ and altitude $312 \mathrm{M}$ to $1178 \mathrm{M}$ above mean sea level), and brought to the laboratory in ice bags. The DNA was extracted from half the quantity of collected fresh leaves on the same day and the remaining half was kept at $50^{\circ} \mathrm{C}$ for overnight.

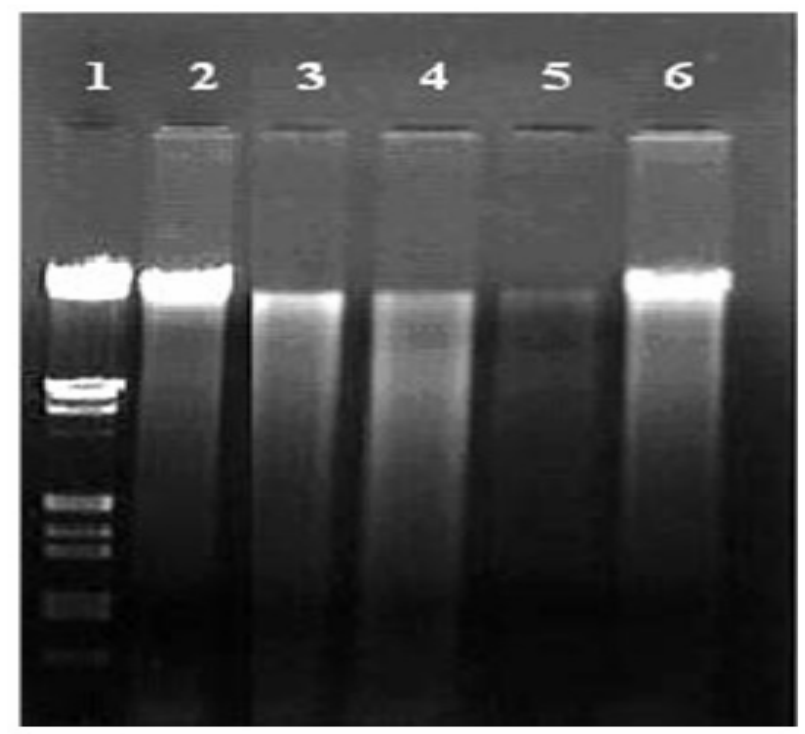

Figure 2. DNA sample digested with Eco R I enzyme from left to right. Lane 1, $\lambda$ DNA digested with Eco R I and Hind III; lane 2: Terminalia arjuna fresh leaves; lane 3: Terminalia tomentosa fresh leaves; lane 4: Terminalia tomentosa dry leaves; lane 5: Terminalia bellerica fresh leaves; lane 6: Terminalia arjuna dry leaves.

\section{Reagents and chemicals required}

- HEPES (1 M); polyvinylpyrrolidone; $\beta$ mercaptoethanol; 25\% sucrose; Tris-Cl pH 8.0 (1 $\mathrm{M})$; EDTA pH 8.0 (0.5 M); $\mathrm{NaCl}(5 \mathrm{M})$; SDS $(10 \%)$; ammonium acetate $(7.5 \mathrm{M})$; isopropanol; ethanol; chloroform; isoamyl alcohol (24:1) (v/v).

- Wash buffer: $100 \mathrm{mM}$ HEPES, $0.1 \%$ (w/v) polyvinylpyrrolidone, $4 \% \beta$-mercaptoethanol (v/v) (added immediately before use).

- Extraction buffer: sucrose $15 \%$ (w/v), $50 \mathrm{mM}$ Tris-Cl (pH 8.0), 50 mM EDTA (pH 8.0), $500 \mathrm{mM}$ $\mathrm{NaCl}$.

- $\quad$ Resuspension buffer: 20 mM Tris-Cl (pH 8.0), 10 mM EDTA (pH 8.0). 
- TE Buffer: $10 \mathrm{mM}$ Tris-Cl (pH 8.0) and $1 \mathrm{mM}$ EDTA (pH 8.0).

\section{DNA isolation protocol}

- Grind $300 \mathrm{mg}$ of fresh leaves (for dry leaves 50 $\mathrm{mg}$ ) in liquid nitrogen.

- Transfer the material to $1.5 \mathrm{ml}$ microfuge tube and add about $1000 \mu \mathrm{l}$ of wash buffer. Vortex the sample for 5 min to remove polyphenols.

- $\quad$ Spin at $12,000 \mathrm{~g}$ for $3 \mathrm{~min}$.

- Remove the supernatant and repeat the washing step 4 to 5 times to take out sticky residues from the precipitant.

- Add $1000 \mu \mathrm{l}$ of extraction buffer to the precipitant and centrifuge at $8,400 \mathrm{~g}$ for $5 \mathrm{~min}$.

- Remove the supernatant and add $450 \mu \mathrm{l}$ of resuspension buffer to the precipitant along with $80 \mu \mathrm{l}$ of $10 \%$ SDS and incubate at $70^{\circ} \mathrm{C}$ for 15 min.

- Allow the sample to cool to room temperature, then add $300 \mu \mathrm{l}$ of $7.5 \mathrm{M}$ Ammonium acetate and place the sample on ice for $30 \mathrm{~min}$.

- Spin at $12,000 \mathrm{~g}$ for $15 \mathrm{~min}$.

- Carefully transfer the upper clear aqueous layer to another $1.5 \mathrm{ml}$ microfuge tube.

- Add equal amount of ice-cold isopropanol and centrifuge for $15 \mathrm{~min}$ at $12,000 \mathrm{~g}$.

- Discard the supernatant and wash the pellet twice with $70 \%$ ethanol.

- $\quad$ Dry the pellet and dissolve it in $100 \mu \mathrm{TE}$ buffer.

- Add $10 \mu \mathrm{l}$ of RNaseA $(10 \mu \mathrm{g} / \mathrm{ml})$ and incubate at $37^{\circ} \mathrm{C}$ for $1 \mathrm{hr}$.

- Extract with equal volume of chloroform: isoamyl alcohol (24:1).

- $\quad$ Spin at $12,000 \mathrm{~g}$ for $10 \mathrm{~min}$.

- Transfer the aqueous layer to a fresh $1.5 \mathrm{ml}$ microfuge tube and add 2 volumes of ice-cold ethanol.

- Spin at $12,000 \mathrm{~g}$ for $5 \mathrm{~min}$ at room temperature.

- Wash pellet with $70 \%$ ethanol.
- Dry the pellet in vacuum and dissolve in $100 \mu \mathrm{l}$ of TE buffer or sterile double distilled water and store at $-20^{\circ} \mathrm{C}$ until use.

- The DNA content can be checked by running on $0.7 \%$ agarose gel or by taking absorbance at 260 $\mathrm{nm}$.

- Use about $2 \mu \mathrm{g}$ DNA for restriction digestion and $25 \mathrm{ng}$ for PCR amplification.

\section{Restriction digestion}

Genomic DNA $(2-4 \mu \mathrm{g})$ was digested for $1 \mathrm{hr}$ with 5 to 10 $\mathrm{U}$ of restriction enzyme under optimal temperature and buffer, following manufacturers recommendations (Fermentas, USA). The digested DNA fragments were fractionated on $0.7 \%$ agarose at $5 \mathrm{~V} / \mathrm{cm}$.

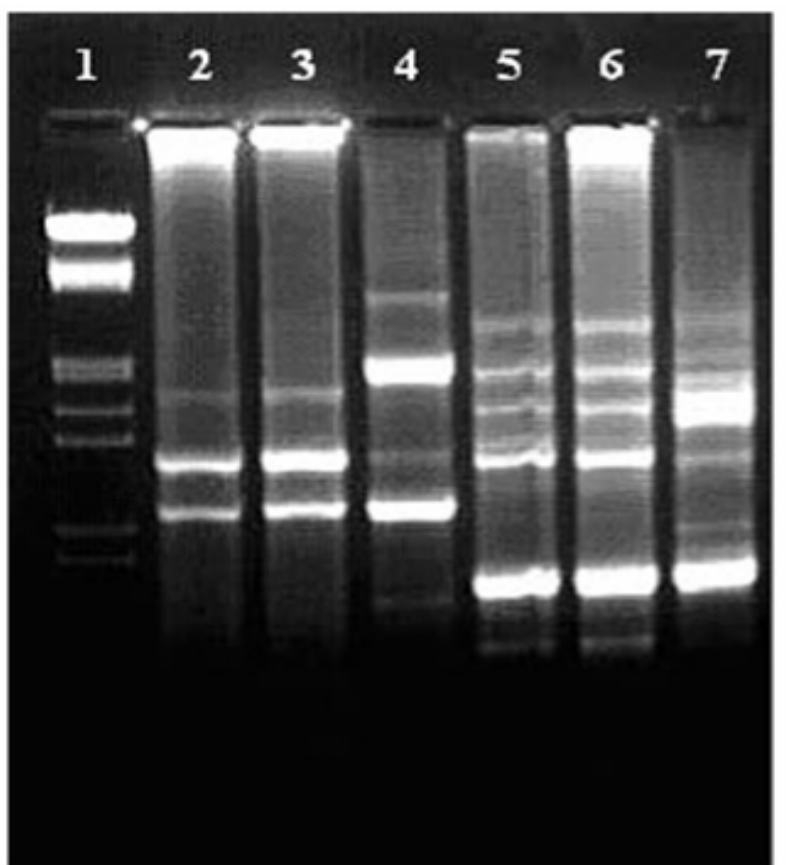

Figure 3. RAPD pattern of PCR amplified products on $1.2 \%$ agarose gel with OPA-20 primer from left to right. Lane 1: $\lambda$ DNA digested with Eco R I and Hind III; lane 2: Terminalia arjuna fresh leaves; lane 3: Terminalia arjuna dry leaves; lane 4: Terminalia bellerica fresh leaves; lane 5: Terminalia tomentosa fresh leaves; lane 6: Terminalia tomentosa dry leaves; lane 7:Terminalia chebula fresh leaves.

\section{PCR amplification}

PCR was carried out in $25 \mu$ volume reaction mixture. The reaction mixture contained $25 \mathrm{ng}$ of DNA, $2.5 \mathrm{U}$ Taq DNA polymerase enzyme (Fermentas, USA), $100 \mathrm{mM}$ each dNTP, $2.5 \mathrm{mM} \mathrm{MgCl2}$, 1X Taq DNA polymerase buffer and $10 \mathrm{mM}$ decamer primer (Operon, USA). The plant DNA was amplified using the following conditions with initial denaturation at $94^{\circ} \mathrm{C}$ for $5 \mathrm{~min}$, followed by 45 cycles, denaturation at $94^{\circ} \mathrm{C}$ for $1 \mathrm{~min}$, annealing at $38^{\circ} \mathrm{C}$ for $1 \mathrm{~min}$, 
and extension at $72^{\circ} \mathrm{C}$ for $3 \mathrm{~min}$ and final extension at $72^{\circ} \mathrm{C}$ for $7 \mathrm{~min}$. The PCR products were fractionated on $1.2 \%$ agarose gel using $1 \mathrm{X}$ TAE buffer containing $5 \mu \mathrm{g} / \mathrm{ml}$ ethidium bromide. Double digested $\lambda$ DNA (Eco R I + Hind III) (Fermentas, USA) as molecular marker.

\section{RESULTS AND DISCUSSION}

The secondary metabolites produced by some plants possess important medicinal properties and are used in food, pharmaceutical, cosmetics and pesticide industries (Khanuja et al. 1999). T. arjuna contains ellagic acid, gallic acid, arjunic acid, arjungenin and their glucosides, arjunetin and arjunglucoside I (Bajpai et al. 2005; Pawar and Bhutani, 2005). The isolation of genomic DNA from perennial plants like T. arjuna is difficult due to presence of polyphenols and polysaccharides. During isolation procedure polysaccharides are found to form complexes with nucleic acids forming a gelatinous mass, thereby physically inhibiting the DNA from the action of DNA modifying enzymes e.g. restriction enzymes, DNA polymerase, ligase, etc. (Sharma et al. 2002). The polyphenols isolated along with DNA from $T$. arjuna are converted to several products reacting with proteins, and bring about their oxidation (Loomis, 1974). For the isolation of DNA from species like $T$. arjuna and $T$. tomentosa, we tried several published protocols like CTAB based (Doyle and Doyle, 1990), high salt and PVP (Porebski et al. 1997), high salt and sarcosyl (Sharma et al. 2002), combination of CTAB and SDS (Keb-llanes et al. 2002), using glucose as a reducing agent in standard CTAB protocol (Permingeat et al. 1998), and protocol for other species of Terminalia (Warude et al. 2003). The DNA isolated by above-mentioned methods was sticky, viscous and colored inhibiting the activity of DNA modifying enzymes. To overcome the problem of contaminant homogenization process. We crushed leaves in liquid nitrogen and removed the polyphenols by repeatedly washing 4-5 times using PVP and $\beta$-mercaptoethanol. The polysaccharides were removed using extraction buffer containing high $\mathrm{NaCl}$ concentration. Current protocol yields DNA of high purity and free from polyphenols and polysaccharides from fresh as well as dry leaves of $T$. arjuna, and other Terminalia species (Figure 1). The purity of the DNA sample was confirmed through its $\mathrm{A}_{260} / \mathrm{A}_{280}$ ratio (1.8) and digestion with restriction enzyme EcoRI (Figure 2). On amplification using random amplification of polymorphic DNA (RAPD) primer the isolated DNA shows high intensity bands (Figure 3). In previously reported protocols for isolation of DNA from $T$. arjuna, commercial DNA isolation kit was used (Sarwat et al. 2006). Our method is simple and can be worked out using in -housecompounds, we tried modified protocols with higher concentration of CTAB (Khanuja et al. 1999). High ionic strength of CTAB forms complexes with proteins and most of the acidic polysaccharides (Jones and Walker, 1963); whereas high concentration of $\mathrm{NaCl}$ helps in the removal of polysaccharides (Aljanabi et al. 1999). In our study, we used the different concentrations of CTAB and PVP. However, in all the cases, low concentrations of polyphenols and polysaccharides were present at the end (data not shown). In our protocol, the polyphenols find their way in DNA preparation during the liquid nitrogen prepared reagents and is useful to extract DNA from fresh and dry leaves of Terminalia species.

In conclusion, the current method is simple and reliable for the isolation of genomic DNA from fresh and dry leaves of $T$. arjuna, which is known to be one of the complicated species for the isolation of DNA, due to the presence of a high percentage of secondary metabolites. This method was successfully applied for the isolation of DNA from other species of Terminalia like T. bellerica, T. chebula, and $T$. tomentosa.

\section{ACKNOWLEDGMENTS}

We would like to thank anonymous reviewers for helpful comments. We are thankful to Dr. M.K. Rai, Head, Department of Biotechnology, SGB Amravti University for valuable suggestions and guidance.

\section{REFERENCES}

ALJANABI, S.M.; FORGET, L. and DOOKUN, A. An improved and rapid protocol for the isolation of polysaccharide and polyphenol free sugarcane DNA. Plant Molecular Biology Reporter, September 1999, vol. 17, no. 3, p. 1-8.

BAJPAI, M.; PANDE, A.; TEWARI, S.K. and PRAKASH, D. Phenolic contents and antioxidant activity of some food and medicinal plants. International Journal of Food Sciences and Nutrition, June 2005, vol. 56, no. 4, p. $287-$ 291.

BHARANI, A.; GANGULI, A.; MATHUR, L.K.; JAMRA, Y. and RAMAN, P.G. Efficacy of Terminalia arjuna in chronic stable angina: A double-blind, placebo-controlled, crossover study comparing Terminalia arjuna with isosorbidemononitrate. Indian Heart Journal, March-April 2002, vol. 54, no. 2, p. 170-175.

DOYLE, J.J. and DOYLE, J.L. Isolation of plant DNA from fresh tissue. Focus, 1990, vol. 12, no. 1, p. 13-15.

JONES, A.S. and WALKER, R.T. Isolation and analysis of the deoxyribonucleic acid of Mycoplasmamycoides var. Capri. Nature, May 1963, vol. 198, no. 4880, p. 588-589.

KEB-LLANES, Miguel; GONZALEZ, Gerardo; CHIMANZANERO, Bartolomé and INFANTE, Diógenes. A 
rapid and simple method for small-scale DNA extraction in Agavaceae and other tropical plants. Plant Molecular Biology Reporter, September 2002, vol. 20, no. 3, p. 299a$299 \mathrm{e}$.

KHANUJA, S.P.S.; SHASANY, A.K.; DAROKAR, M.P. and KUMAR, S. Rapid isolation of DNA from dry and fresh samples of plants producing large amounts of secondary metabolites and essential oils. Plant Molecular Biology Reporter, March 1999, vol. 17, no. 1, p. 1-7.

LOOMIS, M.D. Overcoming problems of phenolics and quinones in the isolation of plant enzymes and organelles. Methods in Enzymology, 1974, vol. 31, p. 528-544.

MILLER, Alan 1. Botanical influences on cardiovascular disease. Alternative Medicine Review, December 1998, vol. 3 , no. 6, p. 422-431.

OHRI, D. Genome size and polyploidy variation in the tropical hardwood genus Terminalia (Combretaceae). Plant Systematics and Evolution, September 1996, vol. 200, no. 3-4, p. 225-232.

PASQUINI, Rossana; SCASSELLATI-SFORZOLINI, Giuseppina; VILLARINI, Milena; MORETTI, Massimo; MARCARELLI, Massimiliano; FATIGONI, Cristina; KAUR, Satwinderjeet; KUMAR, Subodh and GROVER, Iqbal S. In vitro protective effects of Terminalia arjuna bark extracts against 4-nitroquinoline-N-oxide genotoxicity. Journal of Environmental Pathology, Toxicology and Oncology, January-March 2002, vol. 21, no. 1, p. 33-44.

PAWAR, R.S and BHUTANI, K.K. Effect of oleananetriterpenoids from Terminalia arjuna - a cardioprotective drug on the process of respiratory oxyburst. Phytomedicine, May 2005, vol. 12, no. 5, p. 391393.

PERMINGEAT, Hugo R.; ROMAGNOLI, Maria V. and VALLEJOS, Ruben H. A simple method for isolating high yield and quality DNA from cotton (Gossypium hirsutum L.) leaves. Plant Molecular Biology Reporter, March 1998, vol. 16 , no. 1, p. 1-6.

POREBSKI, S.; BAILEY, L.G. and BAUM, B.R. Modification of a CTAB DNA extraction protocol for plants containing high polysaccharide and polyphenol components. Plant Molecular Biology Reporter, March 1997, vol. 15, no. 1, p. 8-15.

SARWAT, Maryam; NEGI, Madan Singh; LAKSHMIKUMARAN, Malathi; TYAGI, Akhilesh Kumar; DAS, Sandip and SRIVASTAVA, Prem Shankar. A standardized protocol for genomic DNA isolation from Terminalia arjuna for genetic diversity analysis. Electronic Journal of Biotechnology [online]. January 15 2006, vol. 9, no. $1 . \quad$ Available from Internet: http://www.ejbiotechnology.info/content/vol9/issue1/full/3/ .ISSN 0717-3458.
SCASSELLATI-SFORZOLINI, G.; VILLARINI, L.M.; MORETTI, L.M.; MARCARELLI, L.M.; PASQUINI, R.; FATIGONI, C.; KAUR, S.J.; KUMAR, S. and GROVER, I.S. Antigenotoxic properties of Terminalia arjuna bark extracts. Journal of Environmental Pathology, Toxicology and Oncology, April-June 1999, vol. 18, no. 2, p. 119-125.

SHARMA, Arun Dev; GILL, Prabhjot Kaur and SINGH, Prabhjeet. DNA isolation from dry and fresh samples of polysaccharide-rich plants. Plant Molecular Biology Reporter, December 2002, vol. 20, no. 4, p. 415a-415f.

WARUDE, Dnyaneshwar; CHAVAN, Preeti; JOSHI, Kalpana and PATWARDHAN, Bhushan. DNA isolation from fresh and dry plant samples with highly acidic tissue extracts. Plant Molecular Biology Reporter, December 2003, vol. 21, no. 4, p. 467a-467f. 